it was passed by 170 votes to 66 . The Bill as amended was then reported to the Governing Body and passed by a substantial majority in each of the three orders. The voting figures were as follows:

$\begin{array}{lrc} & \text { For } & \text { Against } \\ \text { Bishops } & 6 & 0 \\ \text { Clergy } & 95 & 3 \\ \text { Laity } & 129 & 7\end{array}$

The Bill was then duly promulgated as a canon of the Church in Wales.

The meeting of the Governing Body over a week-end was an experiment. It may not be repeated. However, a great deal of significant business was transacted, and the meeting may have had a significance surpassing any item of business on its agenda. Recent years have seen a series of defeats for Bills introduced by the Bench of Bishops, defeats which have led to an uneasy relationship between the Bench and the Governing Body. As reported in the last issue of this Journal, that uneasy relationship manifested itself in stark terms at the April 1998 meeting of the Governing Body (see 5 Ecc LJ 126). The September meeting has witnessed a distinct change in attitudes. Many believed that the Bench's readiness to accept the amendment to the Removal of Doubt Bill enabled that Bill to pass without serious opposition. The new atmosphere of 'give and take' on both sides of what threatened to become a traditional divide appears to have restored the consensus decision-making which was the hallmark of Governing Body business until very recently. If consensus has indeed been restored as a result of the September meeting, after only a short period of unease during which decisions which would have been difficult under any circumstances have been taken, then a new era of collegial progress may be about to be inaugurated. This would be a fitting end to the Church in Wales's first eighty years and a good start to the new millennium for it.

\title{
THE GENERAL SYNOD OF THE SCOTTISH EPISCOPAL CHURCH
}

\section{IVOR GUILD}

\author{
Writer to the Signet
}

The General Synod of the Scottish Episcopal Church opened in Edinburgh with Eucharist on 11 th June 1998 and, as usual, lasted for three days. Liturgy and canons formed the greater part of the discussion, but among other topics it was resolved to hold a Provincial Conference in St Andrews in 1999 with the title 'New Millennium, New Parliament, Renewed Church'.

The Liturgy Committee prepared a number of small changes to Funeral Rites and to the Scottish Liturgy 1982 to remove sexist language; questions were asked about what evidence there was to show that such language depressed or offended women; and after considerable discussion the motion for the changes to be approved for the first time was put to the Synod. It was not passed, but might have had a better chance of success if the changes had been put singly.

\section{SEXUALITY}

A private motion on sexuality was passed in which the College of Bishops was asked to appoint a working party to consider Christian perspectives on human sexuality and relationships, including the issues of homosexuality and same-sex rela- 
tions and new human structure. The working party was instructed to give a progress report to the Synod in 1999 and to make recommendations in 2000 regarding practice, doctrine and liturgy. In making appointments to the working party the College was required to take account of the need to appoint persons with relevant knowledge and experience, including representatives from the gay and lesbian community. The hope was expressed that this step might lead to a consensus in the Scottish Church on this emotive subject. a hope which the Lambeth Conference may have dashed.

\section{CANONS}

The canon governing Episcopal Relations has been the subject of repeated changes, and rather than a formal proposal for further changes a Green Paper was submitted with a fresh approach. The paper was approved, and the Faith and Order Board was asked to put in hand the drafting of the necessary legislation. In the Green Paper it was emphasised that bishops are both diocesan and provincial figures, and while it was appropriate that a diocese should choose its own bishop, the province should also have an input. It is therefore proposed that the election should be held at a special meeting of the diocesan synod. But first a preparatory committee, chaired by the Primus, consisting of a bishop, five members of a special panel (made up of two members from each diocese) and an additional four members of the synod of the diocese to which the election was being made would compile a list of between three and five names of suitable candidates for submission to the electoral synod. The committee would first have been supplied by the Standing Committee of the vacant diocese with a profile of that diocese and an account of its current situation, needs and opportunities. The preparatory committee would, in turn, after interviewing candidates and finding out information about them, draw up a profile and full CV of each candidate and submit this to the electors. Any church member would be free to suggest names of candidates to the preparatory committee.

With regard to the actual election, members of the electoral synod would have an opportunity to meet the candidates. In the election process a simple majority in both the house of clergy and the house of laity would secure election. Should there be two inconclusive ballots, a further ballot would be taken with a single transferable vote. While abstentions would not be permitted in the ballots, an elector would be allowed to write "none" if he did not consider any of the candidates suitable, and, if those voting "none" numbered more than a third of all the electorate, the entire process would start again, as it would if the third ballot were inconclusive.

All previous election procedures have been criticised. It remains to be seen if this new method of selection leads to greater satisfaction, and the injection of a new provincial element to a wider approach. If the new bishop is not a success, the diocese will now have someone else to blame.

Two canonical amendments were given a first reading and duly passed. The first was to correct a misprint and to reconcile the canon with the Synod's Rules of Order. The second was more important and was part of the proposal of reform and revisal of the process of clergy discipline and the resolution of situations of pastoral breakdown. The existing Canon 55, headed 'Of Differences and Disputes and of Appeals', is relatively short: unless a bishop is concerned, disputes are referred to the diocesan, who is left with a wide discretion, and with him lies the final decision except in specified cases. That canon of six sections is being replaced with one of fourteen, which is now headed ' $O$ f the Resolution of Situations of Pastoral Breakdown and other Differences and Disputes'. Its opening sentence reads: 'It is the duty of each diocesan bishop and of each cleric to whom the charge of a congregation within that diocese has been committed to maintain the pastoral relationship between that cleric and the congregation, and the maintenance of that relationship is part of the ordinary work of bishops and clergy'. Provision is made for the appointment of a 
conciliator, and for the bishop to head an enquiry if he feels it appropriate. The Episcopal Synod remains the final appeal body (if appeals are competent), and wide discretion is given for regulating procedure. The phrase 'pastoral breakdown' introduces a new definition of the type of situation with which the canon aims to deal.

Two canons came up for a second reading. The first, which dealt with clergy who desire to engage in secular employment, had been accepted by all the dioceses to which it had been remitted during the past year, and was quickly passed. The second, which deals with offences and trials, was criticised as being too legalistic, but, after a number of amendments from the dioceses had been proposed, the canon as amended was accepted. One of the amendments recommended a system of legal support for persons accused under the canon. The new canon runs to forty-nine pages, if appendices and Rules of the Clergy Discipline Tribunal are included, which indicates the detail into which it goes with regard to steps required to be followed.

\section{HOMELESSNESS}

When the Mission Board report was presented, the Synod resolved that it should join the other Churches in Scotland in condemning the fact that homelessness was now a structural part of Scottish life, and called on the government and other relevant bodies to eliminate the evil for the new millennium by providing additional houses at affordable rents. The work of the Scottish Churches Housing Agency was endorsed, and its background paper Challenging Complacency welcomed. A welcome was also given to the government's commitment to the cause of debt remission and the writing-off of the debt of developing countries. Resolutions on such subjects are easily passed when it is for others to take the remedial action, and it could be said that the Church prefers the overturning of the tables in the Temple to discussing with the moneylenders the problem of providing credit in ecclesiastical buildings.

\section{CHURCH UNION}

Appreciation was expressed for the work of other Boards. The Interim report of the Scottish Churches Initiative for Union was commended to dioceses for study, discussion and comment. Concern was expressed that a Declaration of Intent signed with the Methodist Church in 1996 had not been furthered, and the development of more ecumenical projects was encouraged, in the first instance for not longer than three years. The proposal for such a project in Rosyth, Fife, was welcomed, as was the ecumenical project with the Church of Scotland at Mid Craigie in Dundee.

\section{FUND-RAISING}

Money, as always, was an issue, and a Fundraising Unit for the Scottish Church was established with a director to take up post in August. A target for her to aim at was fixed.

\section{CHILD PROTECTION}

The final session of the Synod was largely devoted to the introduction of a Child Protection Policy. Discussion centred around a paper on Safeguarding Children and Young People in the Church, and the code of good practice contained in it. As a result of recent legislation this has been considered by all institutions involved with children, and the Church is giving training to all clergy and voluntary workers connected with the Church. However, concern was voiced about false allegations which might be made against voluntary workers leading to their automatic suspension. There was little safeguard against the damage such automatic response entailed. Lessons could perhaps be learnt from schemes of training which other Churches had initiated. 
With little contention accounts were approved, members re-elected to committees, and retiring members thanked. Goodwill was enhanced by a dinner for delegates after the first day, at which a Catholic priest held the company enthralled by an amusing speech. On the third day the agenda was disposed of, and members dispersed to enjoy the summer, if and when it arrived.

\title{
THE GENERAL SYNOD OF THE CHURCH OF ENGLAND
}

\author{
BRIAN HANSON \\ Registrar and Legal Adviser to the General Slnod
}

This Report covers three Groups of Sessions held in February, July and November 1998

In February the General Synod gave final approval to the Cathedrals Measure (see 4 Ecc LJ 682 and 5 Ecc LJ 64). The voting was Bishops 34, 0; Clergy 174, 0; Laity 193, 3 . At the time of writing, the Measure has been found expedient by the Ecclesiastical Committee of Parliament but awaits debates in both Houses. The National Institutions Measure (see 4 Ecc LJ 682 and 5 Ecc LJ 64) was also finally approved at the February Sessions (Bishops 36, 0; Clergy 181, 11; Laity 175, 27). The Measure received the Royal Assent on 2 July 1998 and is to come into force on 1 January 1999.

Also passed in February was a Statutory Instrument amending the Church Representation Rules to make it possible for a district church council to be designated by the bishop's council of the diocese as a parish for the purposes of producing financial statements in respect of that district instead of consolidating such financial statements in the statements of the whole parish. Draft Amending Canon No 22 was given general approval in February. The purpose of the Canon is to make it possible for the diocesan bishop to grant permission for a form of service which has ceased to be authorised for use in the Church of England to continue to be used for a limited period only in the applicant's place of worship.

At the July 1998 Group of Sessions the draft Care of Places of Worship Measure formerly called the Care of Non-Parochial Places of Worship (see $5 \mathrm{Ecc} \mathrm{LJ} \mathrm{65)} \mathrm{was}$ considered for revision in full Synod. The Revision Committee had amended the Measure in relation to faculty fees. It was considered that it would not be fair to allow non-parochial places of worship who opt to come into the faculty jurisdiction to have the services of the diocesan registrar and chancellor without making any contribution to the costs. After considering various options the Committee decided that the fair way would be to call for payment when such a building needed a faculty and then to charge the normal faculty fees together with an extra fee fixed by the Fees Advisory Commission to take account of the work of the DAC and the archdeacon.

In July the Synod approved a number of subordinate instruments giving effect to changes needed as a result of the passing of the National Institutions Measure. A draft Statutory Instrument amending the Church Representation Rules was given general approval. The amendments mainly deal with modifications to the appeal rules as a result of recommendations made in various election appeal judgments and changes needed as a result of the Charities Act. The Faculty Jurisdiction (Appeals) Rules 1998 were also approved.

At the November Sessions Amending Canon No. 21 was promulged. The Canon amends Canons $\mathrm{H} 2$ and $\mathrm{H} 3$ to give ex officio membership of Convocation to clergy serving as members of the Archbishops' Council.

Final approval was given to the Care of Places of Worship Measure (Bishops 27, 0 ; clergy 150, 0; Laity 171, 1) and it now awaits consideration by Parliament. Draft 